\title{
Mediterranean Geoscience Reviews: a Mediterranean perspective to geosciences
}

\author{
Attila Çiner ${ }^{1} \cdot$ A. M. Celâl Şengör ${ }^{1,2} \cdot$ Nabil Khélifi $^{3}$
}

Published online: 18 June 2019

๑) Springer Nature Switzerland AG 2019

It is our privilege to present the inaugural issue of the Mediterranean Geoscience Reviews, an international scientific journal that will gather several aspects of geology and physical geography related to the Mediterranean basin and surrounding countries (Fig. 1). Peer-reviewed, high-quality, and innovative scientific research and review articles from all major disciplines of geosciences such as tectonics, geophysics, geochemistry, sedimentology, palaeontology, petrology, mineralogy, volcanology, marine geology, natural hazards, geoarchaeology, palaeoenvironment and palaeoclimate studies, geological heritage, geoarchaeology, geomorphology, and physical geography are welcome. One of the purposes of the journal is to embrace all these fields not necessarily like an anthology, but rather in the spirit of a Humboldtian synthesis. It is important to present individual research contributions on the Mediterranean and its frame to international scrutiny, but we hope to do it in a context, where every contribution would say something about how it improves our understanding of general picture of Mediterranean geography.

The Mediterranean domain probably constitutes one of the best-studied regions in the world in terms of its geography and geology. It represents, for instance, a present-day geodynamic analogue for the final stages of a continent-continent collisional orogeny, where the oceanic lithosphere originally found between the Eurasian and African-Arabian plates have been subducted and partially obducted (Cavazza and Wezel 2003), where, however, new oceanic basins are being born at the same time!

Attila Çiner

cinert@itu.edu.tr

1 Eurasia Institute of Earth Sciences, Istanbul Technical University, Maslak, 34469 Istanbul, Turkey

2 Geological Engineering Department, Istanbul Technical University, Maslak, 34469 Istanbul, Turkey

3 Middle East and North African Program, Springer, Heidelberg, Germany
The Mediterranean Sea includes its basin, which is of two separate origins: the western Mediterranean basins are young, mid-to-late Cainozoic structures; the origins of which are intimately related to the evolution of mountain ranges framing them. On the other hand, the eastern Mediterranean is a remnant of the Neo-Tethys, the origin of which goes back to complex events between the Permian and the Lias, with recent claims of even Carboniferous oceanic crust (Granot 2016). Its evolution has led to the creation of the mountain ranges that surround it and the Aegean Basin, which resembles the basins of the western Mediterranean in structure and in origin. While many studies investigated the Cainozoic and present-day tectonic activity of the Mediterranean, its Mesozoic and earlier evolution is much less understood. The lack of the understanding of the early evolution of the Mediterranean system partly explains some of the present debates and controversies as well as competing tectonic and geodynamic models.

Even though impressive amounts of works have been carried out related to the tectonic evolution of the Mediterranean as a whole, there are still several questions that need to be answered. For instance, it is important to understand the evolution of Mediterranean subduction zones and their influence on the mountain ranges created by them (e.g., Royden and Facenna 2018). The connection between mantle convection and surface deformation and the origin of topography are other open questions requiring more integrated programs, where geophysics, geology, and physical geography can be merged together in a general geodynamic picture. The spatio-temporal distribution and the detailed characteristics of earthquakes in the Mediterranean and behaviours of the major fault zones (such as the North Anatolian Fault) and kinematics and evolution of the rift systems in and around the eastern Mediterranean also require further studies.

The cause for the rapid rise of the orogenic plateaux, such as the central and eastern Anatolian Plateaux, is another hot topic that attracted recent interest (e.g., Schildgen et al. 2012, 2014; Gögüş et al. 2017). To that end, the 


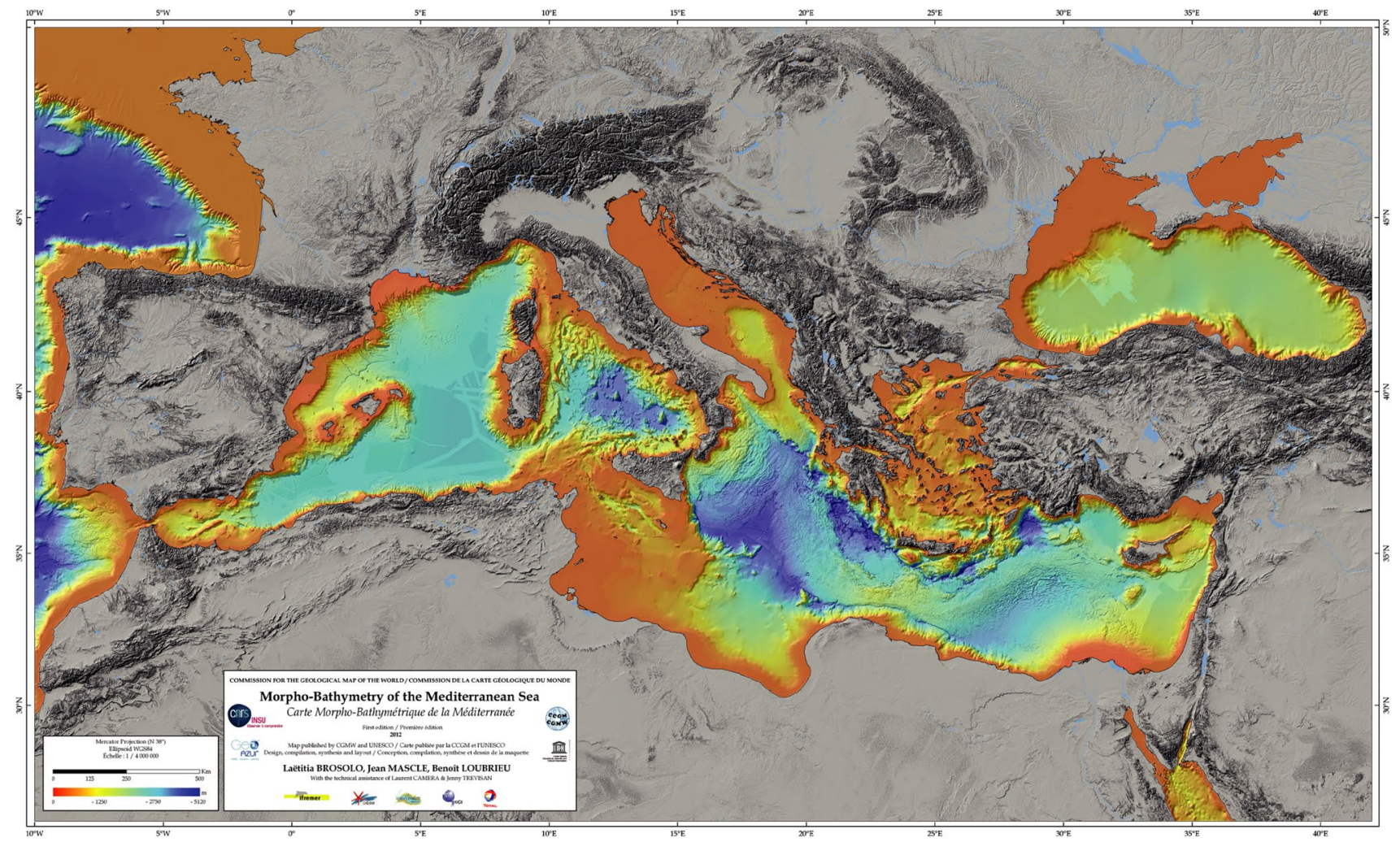

Fig. 1 The Morpho-bathymetric map of the Mediterranean Sea and surrounding regions. The map displays a contrasting view between the continental reliefs, shown in shades of grey, and the Mediterra-

non-isostatic component of the topography (dynamic) for the mountain/plateau construction in the context of mantle dynamics needs to be explored quantitatively. It is also important to explain the potential geodynamic mechanisms (e.g., slab break off, delamination, and plume impingement) that trigger uplift.

Mediterranean is also an important region where a wide range of magmatism and volcanism with different chemical compositions has been observed, although their melting conditions and the depth that they are derived from (asthenospheric, lithospheric mantle) are not clearly established. Active volcanoes and their potential hazards also need to be clearly surveyed. Powerful and catastrophic Minoan-Thera eruption of Santorini, which is one of the largest and beststudied eruptions that occurred in historic times, is an excellent reminder of the impact of volcanoes not only on geography but also on societies (volcanic hazards, tsunamis, etc.).

Major fluvial systems that reach the Mediterranean Sea and their deltas (let us remember that the "type delta" is in the Mediterranean!) that host numerous ancient cities are major topics of interest among geomorphologists and geoarchaeologists. The postglacial sea-level rise and/or local tectonics that created drowned/raised shorelines, marine terraces, and beachrocks in these environments require nean seafloor morphology in colour grading scale. Map by Brosolo et al. (2012)

additional research to be able to see the entire picture with a view to fully appreciating the impact of rapid climatic and environmental changes, on landscapes, on the local biosphere, and on human societies.

Perimediterranean carbonate platforms are another specific and important constituent of the Mediterranean geology, where they form major building blocks of complex mountain chains covering large areas and reaching very significant thicknesses in some cases. In this context, the most important open questions are the still controversial large-scale palaeogeographical patterns, a need for improved biostratigraphic correlation within and between them, definition of regionally recorded depositional events, as well as imperfectly defined depositional architecture of many of the individual platforms.

Carbonate outcrops around the Mediterranean also include outstanding karst areas. They are located relatively close to the Mediterranean coast under the influence of Mediterranean climates. Majority of karst areas are characterized by heterogeneous patchwork of solution landforms, which show few similarities, apart from a clear predominance of bare rock features on the landscape. Some European Mediterranean karst areas were scientifically studied as early as nineteenth century and they still represent the most studied 
areas in the fields of karstology and speleology. One of the most important issues within karst studies is focused on natural resources, including karst aquifers. Apart from oil and other natural resources, karst water resources have been important in the historical and economic development of the Mediterranean region and karst groundwater is of crucial importance today for the sustainable development of the economies in many countries in view of local desertification trends.

Scientific drilling programs such as Deep-Sea Drilling Project (DSDP), Ocean Drilling Program (ODP), Integrated Ocean Drilling Program (IODP), or the new International Ocean Discovery Program (IODP) have elaborated our understanding of the interior of our planet. We now have new tools and methodologies that gave rise to enduring international collaborations in research, education, and public engagement. More and more results are now reported from the hydrocarbon exploration of the eastern Mediterranean. These new discoveries have boosted marine science and resulted in significant acquisition of seismic reflexion data, which provided insights on the palaeogeographic and plate kinematic evolution of the Mediterranean, but very little attention has been given to reconstruction of the oceanic history of the proto-Mediterranean. This reflects mainly the lack of available deep-sea cores that record these intervals (i.e., in addition to seismic reflections). Thus, the study of deep down core sediment records, and their evaluation in the context of marginal and continental archives, will be one of the main future directions.

The so-called Messinian Salinity Crisis, during which the Mediterranean Sea was partly desiccated resulting in the deposition of thick layered and massive salt deposits within the basins, still creates a heated debate among scientists. In light of the new ideas of how to accumulate thick evaporite sequences in deep basins, and thanks to the drilling programs the research should reapproach the Messinian evaporites with new models for various sub-basins combined with a detailed survey of submarine morphology. Additional research directions pertain to the Quaternary history of the Mediterranean, including the history and dynamics of Sapropel events.

Understanding climate change in the Mediterranean Sea today, during the Quaternary, and in the future, has also very important scientific but also societal implications. Therefore, tracing the sediment sources of fluvial and Aeolian sediments, e.g., from the Sahara, the patterns of the drainage systems, and their changes through the Cainozoic, and data from Mediterranean lakes also need to be augmented considerably and better constrained, if we are to understand the long-term trends in palaeoclimatology.

Over Pleistocene and longer timescales, it seems that climate changes were synchronous across the entire Mediterranean. This applies not only to Milankovitch timescales (glacial-interglacial) but also to sub-Milankovitch changes, such as Dansgaard-Oeschger and Heinrich events, including the Younger Dryas. On the other hand, during the current Holocene interglacial, the evidence does not support a common pattern of climate change across the whole Mediterranean basin. During the last millennium, there seems to have been an east-west climate see-saw (Roberts et al. 2012), while, over the last 10 millennia, the dominant pattern seems to have been a contrast between the southeast and the northwest (e.g., Iberia) (Finné et al. 2019). We, therefore, need to understand the reasons behind this contrast.

Last but not least, the development of cosmogenic surface exposure dating methods now allows us to constrain the timing of the retreat of glaciers better and hence paleaeoclimatic changes that occurred since the late Quaternary along the Mediterranean mountains (Hughes and Woodward 2017). Although some periods are very well studied (e.g., Last Glacial Maximum), some others are not (e.g. Holocene). Similarly, some areas are satisfactorily surveyed (e.g., Iberia and Anatolia), but some others require further studies (e.g., Atlas, Dinarides, and Apennines). Overall, an understanding of permafrost conditions since the Last Glaciation and the role of paraglacial activity in shaping the landscape of the highest mountains (rock glaciers, landslides, rock walls, and formation of lakes) across the Mediterranean region are other important topics that need further research (Oliva et al. 2018).

In view of such still open questions and gaps in our knowledge about geology and geography of the Mediterranean region, Mediterranean Geoscience Reviews journal hopes to create a niche where newest research and discussions could be published encompassing all disciplines of geosciences in a Humboldtian spirit.

\section{References}

Brosolo L, Mascle J, Mascle B (2012) Morpho-bathymetry of the Mediterranean Sea; 1:4.000.000 scale. Commission for the geological map of the world

Cavazza W, Wezel FC (2003) The Mediterranean region-a geological primer. Episodes 26(3):160-168

Finné M, Woodbridge J, Labuhn I, Roberts N (2019) Holocene hydroclimatic variability in the Mediterranean: a synthetic multi-proxy reconstruction. Holocene 29(5):847-863

Göğüş HO, Pysklywec RN, Şengör AMC, Gün E (2017) Drip tectonics and the enigmatic uplift of the Central Anatolian Plateau. Nat Commun 8:1638. https://doi.org/10.1038/s41467-017-01611-3

Granot R (2016) Palaeozoic oceanic crust preserved beneath the eastern Mediterranean. Nat Geosci 9:701-705. https://doi.org/10.1038/ ngeo 2784

Hughes PD, Woodward JC (eds) (2017) Quaternary glaciation in the Mediterranean mountains: a new synthesis. Geological Society, London, Special Publications, vol 433, pp 1-24 
Oliva M, Žebre M, Guglielmin MM, Hughes P, Çiner A, Vieria G, Bodin X, Andrés N, Colucci RR, García-Hernández C, Mora C, Nofre J, Palacios D, Pérez-Alberti A, Ribolini A, Ruiz-Fernández J, Sarıkaya MA, Serrano E, Urdea P, Valcárcel M, Woodward J, Yıldırım C (2018) The existence of permafrost conditions in the Mediterranean basin since the Last Glaciation. Earth Sci Rev 185:397-436. https://doi.org/10.1016/j.earscirev.2018.06.018

Roberts N, Moreno A, Valero-Garcés BL, Corella JB, Pablo J, Jones M, Allcock S, Woodbridge J, Morellón M, Luterbacher J, Xoplaki E, Türkeş M (2012) Palaeolimnological evidence for an east-west climate see-saw in the Mediterranean since AD 900. Glob Planet Change 84-85:23-34

Royden LH, Facenna C (2018) Subduction orogeny and the late Cenozoic evolution of the Mediterranean arcs. Annu Rev Earth Planet Sci 46:261-289
Schildgen TF, Cosentino D, Caruso A, Buchwaldt R, Yıldırım C, Rojay B, Bowring SA, Echtler H, Strecker MR (2012) Surface expression of Eastern Mediterranean slab dynamics: neogene topographic and structural evolution of the SW margin of the Central Anatolian Plateau, Turkey. Tectonics 31:TC2005

Schildgen TF, Yıldırım C, Cosentino D, Strecker MR (2014) Linking slab break-off, Hellenic trench retreat, and uplift of the Central and Eastern Anatolian plateaus. Earth Sci Rev 128:147-168

Publisher's Note Springer Nature remains neutral with regard to jurisdictional claims in published maps and institutional affiliations. 